\title{
SEARCH OF SELF-IDENTITY AND CULTURAL RESTLESSNESS IN ALL ABOUT H. HATTERR BY G V DESANI - CRITICAL STUDY
}

\section{Dr Rupa B Dangar}

The Info Anglican fiction in Post Independent India has assumed all kinds of colourful traditions. It has freed itself from the traditionalism and political overtones of a nationalistic variety. Indian literature in English has earned widespread reputation both in India and abroad. It has come to have a significant place in the world's literature. After Raja Tao, Milk Raj Anand and Kamala Markandya, a turn came to Indo Anglian novels. More and more novelists deal with an individual's search for identity; we study the themes concerning an individual character is being shown either unable to face or unwilling to accept the social role. The traditional and conventional society is apt to impose upon the character some conflicts, inner or outer. As a result the dramatic conflict arises out of the individual and Indian concept of supra- individual societies. We come across such themes in G V Desani's All About H. Hatterr, Kamasla Markandya's Possessions and Raja Rao's The Serpent and the Rope. In these novels, the psychological dimensions of this conflict form the centre of the story and interest, while the social, political or economic aspects are pushed into the background.

G V Desani is an Indian author who received high praise in 1940's for his books, novels- psycho- philosophical, and oratory, with his first work All About H. Hatterr, he promised to be an outstanding representative of relations of east and west, of general interpretations. His All About H. Hatterr appeared in 1948 with a grand success. It is based on his scholarly papers in which he gave a learned account of Patanjali's 'Yoga- philosophy'- 'Yoga Darsana'. Like important novels, it provides a sort of education to self. It is modern classic. Even a critic like Eliot has high word to praise it...

"In all my experiences, I have not met anything like it."

All about All About H. Hatterr is an authentic and autodidactic of an individual who seeks 'search of the reality' and 'identity of self' in the crowded universe and surroundings. Moreover Govind Desani presents the various themes, as planned in 
the manner of James Joyce's Ulysses. Desani's present work thus is a fantastic force and is written in exaggerated language. It, thus, remains a comic work that dictates the protagonist's failures in attempt to get 'self-identity' and 'ultimate truth'.

Complex novels always deal with variety of themes and dimensions. In this novel, we find the front line themes like, east west encounter, on philosophic and material basis, search for identity in the midst of national and Cultural restlessness, exploration of reality in the school of life and symbolic representation of the splinters of the westernised Indian Sensibility. With these themes, the hero $\mathrm{H}$. Hatterr - Hindustani wall's talks, experiments, experiences sense and nonsense talks with sages, humor and irony, lofty wisdom and foolish deeds, fantasy and realism all are woven. All these create pathos and bathos in the novel. Moreover it's strangeness of themes and narrative technique defies any simple critical classifications. Hero's experiences with different sages cannot be expressed in conventional and plane form of writing. The novel has been formed through stream of consciousness method.

The basic themes of 'search of identity' and 'ultimate truth' are woven round the hero of the novel. The novel is nothing but a graphic imaginative picture of hero's growth of consciousness. His life is a journey of struggles. It shows his movement and growth from Innocence to experience. He tells, though H. Hatterr tells and teaches himself, how to develop and became consciousness and how to get proper education to understand the truth in life, from the large school of life, i.e. society, culture, nation and surroundings.

H. Hatterr the protagonist searches his own identity, as he belongs to different culture parents. Father is a European and mother is a Malayalam woman. $\mathrm{He}$ is adopted by an English missionary school. It helps him to learn and get education. This is how he becomes 'a sahib'. But when his boyhood is over, he begins to aware with the various walks of the world. He finds changes taking place in him. He can think on his likes and dislikes. Thus individual attitude to things and world begin to come in him and he becomes conscious of his own self-identity. But soon he grows fed up with puritanical instructions of Rev the head of H. Hatterr confesses that he found then, the constant childhood occupation, routine, unsuited to his temperament. Others like proctor and Royal Geographical and Asiatic society constitutes his orphan childhood. His realization of self begins when he hears the inner voice "Help other, Help others..." He knew that the most deserving that needs his help, was he. So he decided to chuck the school and gets out into open space of India. He desires to live in India, by winning his bread and curry all on his own. 
In order to adopt a new life ways, he has to lose his early identity, so he gives himself a new name $\mathrm{H}$. Hatterr means 'Hindustani wala Hatterr'. Indian soil and surroundings can offer him freedom from the tyrannical cultures and bondages of religion. He thinks now to acquire knowledge in life through plunging himself into various life experiences. He is tired of emotional starvation and religious principles. All these fail to inspire him. He pines for actual life experiences which can't be mere introspection. Thus he enters in a new life to experience a new life. Being an extrovert he poses himself to the necked realities of life. Therefore in the company of his friend Banerji, he moves from place to place in search of truth of life. Their adventures cover up the whole India. He, thus, tells that learnt from the school of life, all the lessons sweet or bitter. He says,

"I'm debtor both to the Greek and Barbarians"

He meets the sages of Calcutta, has become his personal disciple of the illustrious grey- beards Calcutta sages. Then he meets sages of Rangoon, Madras, Bombay, Delhi, and receives instructions and starts thinking about them. He gets the selfrealization, so he says to himself "Be suspicious, meditate like a male dog, look for the indirect lesson. Reality is not an appearance. Thus he gets clear vision and idea about different presumptions such as youth is ugly age, evil triumphs.

To the sage of Rangoon (now resident of India) H. Hatterr asks "Oh, speak of cupidity, sire.!Oh mercy upon my unworthy! The sages says,

"I command thee, boy! Extinguish

the fire of passion with meditation!"

He gets angry when H. Hatterr asked him, "Is woman worth it?" The sages says, "Speak not of sensuality in the presence of

the sage of Rangoon, son of a dog!"

"Meditate now meditate on any form other than the female form"

$\mathrm{Mr} \mathrm{H}$. Hatterr learns from him- his presumption that cupid is blind, non-rational and anti-aircraft intelligent, enemy and so as his victory.

Then from he with Archbishop Walrus about the age of youth he learns why youth is a desirable age. The saints of Madras tell him that he himself had been prey to cruel passions! He confesses..... 
"I was affiliated with the two inhuman infatuations. To buy and to sell paper and to consume tasty foods"

He then told about his unlimited travel. The sage said,

"I have explored the orient! ein mine own eye to expiate sin to be cleansed of my past and to seek forgiveness."from the souls of creature, I did travel. From him and his talks, half nonsensical and half symbolic, H. Hatterr learns that "Life had always bear contrast." It is full of ease and comforts after learning it perfectly.

In this way, life is a journey to understand the understandable things and walks of life. The series of encounters with bogus saints, sadhus or sages like Sadanand, Anand Giri proves to be an meaningful experiences. From these experiences, he taught himself, what truth is, where it lies, how to obtain it. Once again the theme of destiny is hinted by the novelist Desani. H. Hatterr's marriage provides some bitter experiences in his life. H. Hatterr has now his own philosophy which he reveals to Banerji....

"I say in 20th century, life is contrast." That is my crux- statement.

He finds in life ups and downs, sun and cloud, opposites and similar. Take anything and you will find opposite. It is the self-realization that he gets at the end of the novel. Life is contrast, it's not one way pattern. It is contrast all the way. It contrasts by law. It's not just motley mosaic, not just easy run and Gi-ZenLiu do as you please, contrasts but design in them. He finds that much is still remained to be explored.

In this way, H. Hatterr feels lost as life is an endless journey of self or soul or atman. He becomes egoless, identity less, peace with all creation and God is now his way to see himself. 


\title{
Dangar / Page 54-58
}

\section{Works Cited:}

1. Jussawalla, Feroza F. Family Quarrels: Towards a Criticism of Indian Writing in English. Vol. 17. Peter Lang Pub Inc, 1985.

2. McCutchion, David. "Indian Writing in English: Critical Essays." Calcutta: Writers Workshop, 1969.

3. Ashcroft, Bill, Gareth Griffiths, and Helen Tiffin. The empire writes back: Theory and practice in post-colonial literatures. Routledge, 2003.

4. Burjorjee, Dinshaw Maneck. "The dialogue in GV Desani's all about H. Hatterr." (1974): 191-224.

5. Smith, Eric D. "“Ambiguity at its Best!": Historicizing GV Desani's All About H. Hatterr." ARIEL: A Review of International English Literature 40.2-3 (2009).

6. Singh, Amardeep. "More than "priestly mumbo-jumbo": Religion and authorship in All About H. Hatterr." Journal of Postcolonial Writing 46.1 (2010): 89-100.

\author{
Dr Rupa B Dangar \\ Assistant Professor \\ Department of Languages \\ Bhakta Kavi Narsinh Mehta University
}

